\title{
The Role of Psychological Empowerment on Job Satisfaction among Malaysian Public Sector Workers
}

Aini Azeqa Ma'rof, Danial Aiman Mohd Fadzilan \& Hanina H. Hamsan

To Link this Article: http://dx.doi.org/10.6007/IJARBSS/v11-i12/11933 DOI:10.6007/IJARBSS/v11-i12/11933

Received: 13 October 2021, Revised: 16 November 2021, Accepted: 30 November 2021

Published Online: 19 December 2021

In-Text Citation: (Ma'rof et al., 2021)

To Cite this Article: Ma'rof, A. A., Fadzilan, D. A. M., \& Hamsan, H. H. (2021). The Role of Psychological Empowerment on Job Satisfaction among Malaysian Public Sector Workers. International Journal of Academic Research in Business and Social Sciences, 11(12), 2019-2032.

Copyright: (c) 2021 The Author(s)

Published by Human Resource Management Academic Research Society (www.hrmars.com) This article is published under the Creative Commons Attribution (CC BY 4.0) license. Anyone may reproduce, distribute, translate and create derivative works of this article (for both commercial and non0-commercial purposes), subject to full attribution to the original publication and authors. The full terms of this license may be seen at: http://creativecommons.org/licences/by/4.0/legalcode

Vol. 11, No. 12, 2021, Pg. 2019- 2032

Full Terms \& Conditions of access and use can be found at http://hrmars.com/index.php/pages/detail/publication-ethics 


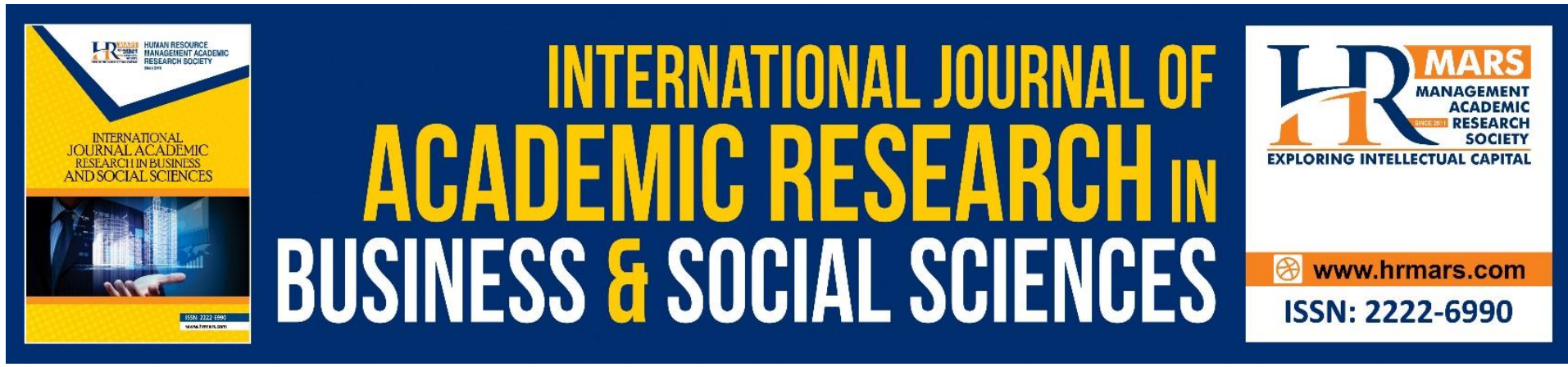

\title{
The Role of Psychological Empowerment on Job Satisfaction among Malaysian Public Sector Workers
}

\section{Aini Azeqa Ma'rof, Danial Aiman Mohd Fadzilan \& Hanina H. Hamsan}

Faculty of Human Ecology, Universiti Putra Malaysia, 43400 Serdang, Selangor Darul Ehsan, Malaysia.

Email: azeqa@upm.edu.my

\begin{abstract}
A number of recent research studies have demonstrated the presence of a positive association between working environment and psychological factors on work satisfaction. Therefore, this study aimed at determining the relationships between workplace friendship, psychological empowerment and organizational commitment on job satisfaction among public sector workers. A total of 356 employees participated in this study where results revealed that the majority of the employees have a high level of workplace friendship, psychological empowerment, organizational commitment and job satisfaction. Besides, workplace friendship and psychological empowerment showed a significant relationship with job satisfaction, meanwhile, no significant relationship between organizational commitment and job satisfaction was shown. Moreover, psychological empowerment has been identified to be the unique predictor that leads to job satisfaction among employees. Findings of this study suggested that psychological training and programs might be effective and crucial to be regularly implemented in order to boost employees' motivations and job satisfaction that later benefits the organization. The theoretical impact and suggested intervention will be discussed in detail.
\end{abstract}

Keywords: Work Satisfaction, Workplace Friendship, Psychological Empowerment, Organizational Commitment, Public Sector Workers.

\section{Introduction}

Job satisfaction is one of the most widely researched elements in the field of workplace psychology (Lu et al., 2012). It is associated with psychosocial issues that range from leadership problems to the need to design jobs. There are various definitions put forward by researchers in occupational and organizational psychology. According to Locke (1973), job satisfaction is a positive emotional state that emerges from a person's judgement of his or her accomplishments or the extent to which a person's job value can be increased. Whereas Spector (1997) defines job satisfaction as the degree to which an individual enjoys or feels content with their job or dislikes or feels dissatisfaction. 
According to Jitendra and Mini (2013), job satisfaction is inextricably linked to employee feelings and emotions during and after completing a task. Meanwhile, according to Aziri (2011) defines job satisfaction as a sum of employee's positive and negative feelings and perceptions of their job. In fact, the underlying meaning of job satisfaction might differ for each individual. For instance, there are individuals who feel satisfied if they can choose a job based on interest, while others may get the sense of satisfaction by task completion and even those satisfied when there is a reward awaiting (Saner \& Sadikoglu, 2016). Therefore, job satisfaction is an important mechanism to investigate as it serves as the crucial factor that leads to recognition, income, promotion, and the accomplishment of other goals that contribute to a sense of fulfilment (Kaliski, 2007). This study thus intends to investigate further factors that explains one's job satisfaction from the environmental and psychological context.

\section{Literature Review}

\section{The Impact of Job Satisfaction on Organisation}

Job satisfaction act as the determinant of an individual health and well-being level. Low level of job satisfaction can affect job productivity and result in a decrease organization performance (Faragher et al., 2005). Studies conducted by Nadinloyi et al (2013) revealed that job satisfaction is a strong predictor of mental health, depression, and social behaviour in an organization. Additionally, Lee et al (2009) discovered that employees with low levels of job satisfaction were found to experience severe psychological stress. Meanwhile, according to Piko (2006), low job satisfaction will affect the physical health of the employee where they are prone to psychosomatic problems (e.g., back pain, headaches, fatigue, sleep problems and gastro-intestinal problems). This shows that an individual job satisfaction is closely related not only to mental health but also physical health. Nonetheless, research indicates that job satisfaction has a significantly greater impact on individual's mental or psychological health (fatigue, sadness, and anxiety) than subjective physical illness (Faragher et al., 2005).

From a psychological point of view, job satisfaction may affect an individual's thoughts, feelings and behaviour. According to Olatunde and Odusanya (2015), individual's health and well-being can be affected due to job dissatisfaction. Individuals are said to be in good health if they can sustain a happy feeling and a sense of satisfaction while performing a task. Therefore, job satisfaction is important to be taken seriously in order to avoid the emergence of other psychosocial problems. Considering the limited studies on job satisfaction from the Malaysian context particularly public sector workers, this study focuses on determining factors associated to job satisfaction and further explore the unique predictor that influence one's job satisfaction.

\section{Relations between Environmental and Psychology Factors on Job Satisfaction}

Job satisfaction has a significant impact on job security, organizational commitment, and employee loyalty. Nevertheless, the work environment and psychological factors plays important role on the physical and mental health of employees. These aspects include the job workload, organizational management and working conditions or environment that fulfil the demands of employees. These includes workplace friendship, psychological empowerment and organizational commitment. 


\section{Organizational Commitment and Job Satisfaction}

Organizational commitment refers to the degree to which individuals identify with the organisation for which they work, their level of engagement with the organization, and their willingness to leave (Greenberg \& Baron, 2008). According to Porter et al., (1974), there is a strong correlation between organizational commitment and job satisfaction in which those with high commitment to the organization are less likely to leave the organization. Organizational commitment is thought to be more important than job satisfaction because it relates to the positive attitude an employee has, not towards his job but towards the organization. In this regard, the emotional element plays an important role in shaping organizational commitment and it is characterized by the employee attachment to the company and readiness to make sacrifices for the organization's benefit.

Studies related to the relationship between job satisfaction and organizational commitment have been extensively conducted (Mathieu \& Zajac, 1990; Martin \& Bennett, 1996; Meyer et al., 2002; Morrow, 2011). However, the question that arises is whether work commitment influences job satisfaction or the other way around. Several studies support the hypothesis that job satisfaction will influence organizational commitment (Tsai \& Huang, 2008; Yùcel, 2012; Valaei \& Jiroudi, 2016). While other studies shows that organisational commitment contributes to work happiness (Curry et al., 1986; Vandenberg \& Lance, 1992). Nonetheless, it is clear that organisational commitment positively correlates with job satisfaction and yet to be explored from a different cultural and environmental context.

\section{Psychological Empowerment and Job Satisfaction}

Psychological empowerment is defined as an individual's perception or attitude toward work and their role in the organization (Conger \& Kanungo, 1988). Meanwhile, Thomas and Velthouse (1990) define psychological empowerment as a set of employees' cognitions regarding their work position, which includes four elements: meaning, efficiency, determination, and impact. There has been a surge in interest in the study of psychological empowerment as a means of facilitating the formation of an excellent organizations. Studies revealed that psychological empowerment plays an important role in producing quality work and a positive environment (Macsinga et al., 2015). This is because psychological empowerment is inextricably linked to individual leadership empowerment, i.e., it directly increases job satisfaction and creativity as well as boosts employee morale and effort for organizational performance (Amundsen \& Martinsen, 2015).

Marius and Sebastian (2010) found a significant relationship between psychological empowerment to job uncertainty and employees' involvement in the organization. Psychological disempowerment results in employees' failure to manage their emotions and thoughts, which impairs their capacity to complete duties, undermines their self-confidence and eventually invites crises not just internally, but also among colleagues and organizations. On the other hand, employees will be actively involved when they are given the opportunity to be involved in planning the organization and this in turn contributes directly to the positive improvement of work performance and the production of ideas for innovation and creativity (Yi et al., 2015). Employee's perceptions of organizational leadership empowerment and psychological empowerment are also the main predicting factors of the employee intention to develop their career in the organization or resign (Jani et al., 2015). Even previous studies 
have proven the importance of psychological empowerment in enhancing job satisfaction, however, there are still limited studies to prove its importance from the Malaysian context.

\section{Workplace Friendship and Job Satisfaction}

There are many functions resulting from the formation of friendships in the workplace in addition to forming values that can bring the greatest benefits to the individual personality. Previous research in psychology, sociology, and management has found that friendships in the workplace can influence job-related attitudes, intentions, and behaviours such as job satisfaction, job performance, intention to remain in the organization, and absenteeism rates in the workplace (Riordan \& Griffeth, 1995; Ross, 1997). According to Dotan (1997), employees who have a good and trustworthy relationship with their co-workers create room for them to share information or seek advice from their co-workers. Thus, the employee will feel more motivated, secure, and satisfied at work as a result of this support system.

Additionally, the presence of friendships in the workplace will form altruistic behaviour, which is the proclivity to provide help, guidance, advice, feedback, or suggestions on any subject, regardless of whether it is work-related or personal. This social support will indirectly develop an internal strength, which will aid a person in progressing and feeling satisfied with their job as a result of the support received. Additionally, studies indicate that workplace friendships can improve organizational performance because the very nature of friendship is that it involves assisting one another in completing a task, increasing work ethic and positive communication, all of which contribute to increased employee effort and productivity (Bandura, 1982). Indeed, friendships at work will lower the likelihood for someone to move workplace or leave the organization compared to those who do not have good friends at work because of their sense of belonging and obligation to help other co-workers who have accepted, understood, and helped them which directly contributes to their job satisfaction (Morrison, 2004).

\section{Method}

\section{Data Collection}

A quantitative approach using a self-administered questionnaire was adopted by using a cross-sectional design method. In order to collect primary data, questionnaires were distributed randomly to government workers in Putrajaya. Before distributing the questionnaires to the employees, a questionnaire needed to be emailed to the director of every unit to randomly select respondents.

\section{Measurements}

Workplace friendship. Workplace Friendship Scale is a questionnaire that is developed by Nielsen, Jex \& Adams (2000). In this questionnaire, workplace friendship is divided into two aspects. This instrument is used to measure the two aspects of workplace friendship which is friendship prevalence and friendship opportunity (Nougarou, 2017). The consistency reliability (Cronbach's Alpha) for this instrument is 0.89 . There are 12 items in this questionnaire, for instance "I am able to work with my co-wokers to collectively solve problems", "In my organization, I have the opportunity to talk informally and visit others". Respondents were asked to rate to the statement on a four-point Likert scale ranging from 1 (strongly disagree) to 5 (strongly agree). 
Psychological empowerment. Psychological Empowerment Scale is a questionnaire that have been developed by Spreitzer (1995). This questionnaire is used to measure the psychological empowerment of an employee. The scale in this questionnaire is being divided into four subdimensions which is meaning, competence, self-determination and impact. The consistency reliability for this instrument is 0.80 . This questionnaire consists of 12 items, for instance, "I have significant autonomy in determining how I do my job", "My job activities are personally meaningful to me". Respondents were asked to rate to the statement on a sevenpoint Likert scale ranging from 1 (very strongly disagree) to 7 (very strongly agree).

Organizational Commitment. Organizational Commitment Questionnaire (OCQ) is a questionnaire that is developed by Mowday et al., (1979). This questionnaire is used to measure the commitment of an employee towards the organization he serves. There are 15 items in this questionnaire which 9 of the questions are the items to measure affective commitment while another 6 more items are used to measure continuance commitment, for instance, "I feel very loyalty to this organization", "I would accept almost any type of job assignment in order to keep working for this organization". Respondents were asked to rate to the statement on a seven-point Likert scale ranging from 1 (strongly disagree) to 7 (strongly agree). The consistency reliability for this questionnaire is 0.81 .

Job satisfaction. Minnesota Satisfaction Questionnaire (MSQ) is a questionnaire that is developed by Weiss et al., (1967). This questionnaire is used to measure the satisfaction of an employee towards his job. The purpose of this questionnaire is also to provide chance to the respondent to express their feeling about their current work, things that satisfy them and also things that dissatisfy the employee (Weiss et al., 1967). Respondents were asked to rate to the statement on a five-point Likert scale ranging from 1 (very satisfied) to 7 (satisfied). The consistency reliability for this questionnaire is 0.89 .

\section{Results}

Table 1 shows the demographic frequency and percentage of the respondents that involved in this current study. A total of 356 employees which is 211 of them were female $(59.27 \%)$ while another 145 employees were male (40.73\%) were involved in this study. As for the age of the respondents, 34 (9.55\%) aged 25 years old and below, 156 (43.82\%) aged 26-35 years old, 120 (33.71\%) aged $36-45$ years old and followed by 46 employees (12.92\%) aged 46 years old and above. 
Table 1 Respondent's background

\begin{tabular}{llll}
\hline Variables & & $\mathbf{N}$ & $\%$ \\
\hline Age & 25 and below & 34 & 9.55 \\
& $26-35$ years & 156 & 43.82 \\
& $36-45$ years & 120 & 33.71 \\
& 46 and above & 46 & 12.92 \\
Gender & Male & & \\
& Female & 211 & 59.27 \\
Monthly Income & & 145 & 40.73 \\
& RM 2,000 or less & & \\
& Between RM 2,001 to RM 4,000 & 158 & 42.75 \\
& Between RM 4,001 to RM 6,000 & 63 & 17.70 \\
& Between RM 6,001 to RM 8,000 & 45 & 13.89 \\
& RM 8,001 and above & 9 & 2.53 \\
Years of Working & & & \\
& Less than 1 year & 18 & 5.06 \\
& 1 to 4 years & 128 & 35.96 \\
& 5 to 10 years & 93 & 26.12 \\
& More than 10 years & 117 & 32.87
\end{tabular}

Note: $\mathrm{N}=$ frequency, $\%$ = percentage

Next, for the monthly income, 81 employees (22.75\%) received RM 2,000 or less a month, 158 employees (44.38\%) have monthly income between RM 2,001 to RM 4,000, 63 employees (17.70\%) received between RM 4,001 to RM 6,000 a month, 45 employees (13.89\%) received between RM 6,001 to RM 8,000 a month and 9 employees (2.53\%) received RM 8,001 and above as their monthly income. For the years of working, 18 employees (5.06\%) work less than 1 year, 128 employees (35.96\%) work between 1 to 4 years, 93 employees (26.12\%) work between 5 to 10 years and another 117 more employees (32.87\%) work more than 10 years.

Table 2 Correlation between workplace friendship, organizational commitment, and psychological empowerment on job satisfaction.

\begin{tabular}{lcc} 
& Job Satisfaction & \\
\hline & $\boldsymbol{r}$ & $\mathbf{p}$ \\
Workplace Friendship & $.24^{* *}$ & .008 \\
Psychological Empowerment & $.27^{* *}$ & .003 \\
Organizational Commitment & .14 & .139 \\
\hline
\end{tabular}

Table 2 shows the correlation test between workplace friendship, psychological empowerment, organizational commitment and job satisfaction. Based on the result, the workplace friendship has a significant relationship with job satisfaction, $r=0.24, p<0.05$. This shows that respondents that have high level of workplace friendship will have a higher tendency to be more satisfied with their work. This is supported by a study by Stepanek (2015) 
which found that friendship influenced employee's work satisfaction positively. Meanwhile, psychological empowerment reported to have a significant positive relationship with job satisfaction, $r=0.27, p<0.05$. This result shows that respondents who have high level of psychological empowerment will also have a high level of job satisfaction. It is said that psychological empowerment has an important impact towards the work satisfaction of a worker (Naser \& Afnan, 2013). On the other hand, organizational commitment has no significant relationship with job satisfaction, $r=0.14, p>0.05$. This shows that there is no relationship between organizational commitment and job satisfaction. In other words, employee's work satisfaction was not influenced by their commitment towards the organization that they serve. Previous study by Norizan (2012) also found that organizational commitment has no positive relationship with work satisfaction. Overall, from this study it could be concluded that only workplace friendship and psychological empowerment that have positive significant effects towards job satisfaction.

Table 3 Multiple regression of the main predictor of job satisfaction.

\begin{tabular}{|c|c|c|c|c|c|}
\hline Predictors & B & SE & $B$ & $\mathbf{t}$ & Sig. (p) \\
\hline Workplace Friendship & .315 & .74 & .18 & 1.74 & .05 \\
\hline Psychological Empowerment & .295 & .45 & .25 & 2.26 & .00 \\
\hline $\mathrm{F}$ & 42.4 & & & & \\
\hline$d f$ & 3 & & & & \\
\hline $\mathrm{R}$ & .31 & & & & \\
\hline$R^{2}$ & .10 & & & & \\
\hline Adjusted $\mathrm{R}^{2}$ & .26 & & & & \\
\hline
\end{tabular}

Note: $B=$ Unstandardized Coefficient Beta, $\beta$ Standardized Coefficient Beta, $t=t$ value, Sig. $(p)$ $=$ Significant $\mathrm{t}$-value

Meanwhile, multiple regression analysis was used to test if workplace friendship and psychological empowerment were able to predict job satisfaction significantly. Based on Table 3 , both workplace friendship $(b=.18, p=.05)$ and psychological empowerment $(b=.25$, $p<.00)$ significantly contributed to the prediction of job satisfaction among respondents with the predictors explained 17 percent of the variance. However, psychological well-being showed the strongest proportion of variance in job satisfaction, $F(3,353)=42.4, p<.001$. This result has been supported by previous study (meta-analysis; Li, Shi, Xing, Wang, et al., 2018). Adding to this, Naser and Afnan (2013) addressed that in order to enhance the work satisfaction of an employee, it is necessary and crucial to empower the intrinsic motivation of the employee whereby considering one's authority and acknowledge their skills into plan making decisions.

\section{Discussion}

This study revealed that employees have relatively high job satisfaction whereby it was significantly associated to workplace friendship and psychological empowerment. However, organizational commitment does not correlate with job satisfaction within this sample. This study thus clearly shows that one's commitment to their organization or psychologically attach to their organization may not contribute to their job satisfaction but workplace friendship and a sense of control in regard to their work and an active engagement within their job rule that will enhance their intrinsic motivation that further enhance job satisfaction. 
These results have been supported by previous studies. For instance, according to Hamilton (2007), when people are involved in a workplace friendship, they may feel more at ease with their colleagues, alleviating feelings of insecurity and uncertainty. Additionally, they share more information and empathies with co-workers regarding work-related issue and concerns. This could say that increase workplace friendship and resources may assist employees in completing their jobs, offer works of encouragement, confidence, trust, respect, critical feedback which further boost enthusiasm and a positive attitude. This emotional and physical support further supported by the study findings that increase in psychological empowerment associated positively with job satisfaction.

Additionally, psychological empowerment revealed as the strongest predictor to employee's job satisfaction. This study suggests that it is crucial for managers to have employees with high level of psychological empowerment, since this demonstrates that they view themselves as competent to do their jobs, have influence over actions in their work environment, perceive themselves as effective, and value their work. Psychologically empowered individuals are said to be more satisfied with their jobs and more committed to their organization (Seibert et al., 2011).

Overall, this study suggests that job satisfaction is critical for managers to consider because it is associated with a number of desirable organisational outcomes, including high productivity, low absenteeism, and low turnover rates (Yang \& Wang, 2013), as well as mental and physical health (Shahmohammadi, 2015), all of which are desired by any organisation. Employees that are most satisfied with their jobs are more likely to recognise the organization's value and goals and will stay with the organization (de Lourdes Machado et al., 2011). Employees will be satisfied if they perform their jobs enthusiastically and are recognized for their efforts (Avram et al., 2015). The organization effectiveness is dependent on employee work satisfaction, yet it should be noted that job satisfaction is a subjective judgement that varies from individual to individual and hence varies significantly (Belias et al., 2015).

\section{Implications and Recommendations}

\section{Psychological Empowerment as a Significant Contributor to Job Satisfaction}

Psychological empowerment involves employees' belief on the importance or meaning of their career, their ability to perform effectively on the job, the ability to set career direction and the power of autonomy given in influencing their work outcome. Spreitzer (1995) explains that these four elements of cognition will form the next construct of psychological empowerment if they are met and acknowledged by all employees, and if the organization assists employees in their self-growth as well as the organization's development. In summary, our findings show that empowerment programmes should prioritise attaining optimal levels across all dimensions in order to build a balanced combination that produces the most beneficial consequences.

Number of studies on organizational excellence have discovered that psychological empowerment can significantly boost an individual's work ethic and job performance. In fact, psychological empowerment has a direct effect on job satisfaction and raises the rate of organizational commitment (Durrah et al., 2016). Although in general empowerment in terms of organizational structure has a direct positive effect on the efficiency and layout of an organization, it also contributes to employee emotional exhaustion. As a result of this 
emotional exhaustion in turn may decrease the employees' commitment to the organization (Cho et al., 2006). This demonstrates that one of the primary pillars to consider when determining employee motivation and momentum is the extent to which their psychology is empowered by providing space and opportunities for employees to make decisions, make recommendations, and equally contribute to the organization's performance.

Overall, psychological empowerment is seen as a major contributing factor to job satisfaction. This is supported by this study where job satisfaction among government officials shows that psychological empowerment not only has a positive relationship on job satisfaction, but it is also a major contributing factor to one's job satisfaction compared to workplace friendship and organizational commitment. This suggest that by enhancing and maintaining the psychological element of employees by providing authority and acknowledge their roles in the organization may help to increase employee's motivation and momentum in contributing towards organizational excellence.

\section{Increasing the Empowerment of Organizational Psychology}

Psychological empowerment is the degree to which an individual feels competent in a proactive work environment and capable of successfully completing a task. This feeling in turn will boost the individual's sense of responsibility and commitment to the organization, as well as their loyalty to the organization and encourage work performance, when compared to individuals with low psychological empowerment. In order to empower the psychology of the individual, there are several key elements that need to be consider. Firstly, is the value placed by an individual on the purpose and goals of their work, i.e., the ideals and standards established by the individual from the beginning (Thomas \& Velthouse, 1990). According to May et al (2004), the value placed on a job is seen as a method to cultivate employee motivation and attachment to their job and involves continuous engagement. Additionally, by giving a high meaning and value to a job, it will increase individual's competence and confidence as long as full trust is given for the individual to complete the task by according to their skills and not according to others' instructions. This is because, Maslach et al (2001) found a strong relationship between self-efficacy and job satisfaction. Thus, the freedom and trust given by the organization to the employees to compete a task is important in influencing a person's inner spirit to remain productive at work.

Moreover, the power of autonomy plays an important role in empowering the psychological element in the organization that will lead to job satisfaction (Bakker \& Demerouti, 2008). The autonomy given includes giving employees the opportunity to make decision, make suggestions and views, and choose their own way based on skills and knowledge to solve problem instead oof having to follow others. The trust given is very important as this will make the employees feel valued and both contribute to the organization's excellence through innovation. Overall, the emphasis on individual psychological empowerment has a substantial impact on job satisfaction since it entails an appreciation for one's skills, talents, knowledge, and the sense of togetherness and belonginess in the organization.

\section{Conclusion}

Job satisfaction is important for an organizational existence. It will ascertain the level to which employees are engaged with the organization by considering their physical, cognitive, and emotional contributions to the organization. In order to help employees in remaining 
proactive and productive throughout their careers, despite physical factors such as salary and remuneration, as well as environmental factors such as peer support and adequate facilities, the primary factor that contributes to jobs satisfaction is the psychological factors. Thus, psychological empowerment is important and has proven successful in gaining the hearts and minds of employees as well as improving employee performance (Avolio, et al., 2004; Seibert et al., 2004). Psychological empowerment is said to be the key catalyst to jo satisfaction because a sense of direct and valued involvement makes employees more committed and eager to equally help to increase organizational productivity.

\section{Reference}

Amundsen, S., \& Martinsen, $\varnothing$. L. (2015). Linking empowering leadership to job satisfaction, work effort, and creativity: The role of self-leadership and psychological empowerment. Journal of Leadership and Organizational Studies, 22(3).

Avolio, B. J., Zhu, W., Koh, W., \& Bhatia, P. (2004). Transformational leadership and organizational commitment: Mediating role of psychological empowerment and moderating role of structural distance. Journal of Organizational Behavior, 25, 951968.

Avram, E., lonescu, D., \& Mincu, C. L. (2015). Perceived safety climate and organizational trust: the mediator role of job satisfaction. Procedia-Social and Behavioral Sciences, 187, 679-684.

Aziri, B. (2011). Job satisfaction: a literature review. Management Research and Practice.

Bakker, A. B., \& Demerouti, E. (2008). Towards a model of work engagement. Career Development International.

Bandura, A. (1982). Self-efficacy mechanism in human agency. American Psychologist, 37(2), 122-147.

Belias, D., Koustelios, A., Vairaktarakis, G., \& Sdrolias, L. (2015). Organizational culture and job satisfaction of Greek banking institutions. Procedia-Social and Behavioral Sciences, 175, 314-323.

Cho, J., Laschinger, H., \& Wong, C. A. (2006). Workplace empowerment, work engagement and organizational commitment of new graduate nurses. Nursing leadership, 19(3), 43-60.

Commitment and motivation at work: The relevance of employee identity and regulatory focus. The Academy of Management Review, 35(2), 226-245.

Conger, J. A., \& Kanungo, R. N. (1988). The empowerment process: Integrating theory and practice. The Academy of Management Review, 13(3), 471-482.

Curry, J. P., Wakefield, D. S., Price, J. L., \& Mueller, C. W. (1986). On the causal ordering of job satisfaction and organizational commitment. Academy of Management Journal, 29, 847-858.

Machado, de L. M., Brites, R., Magalhães, A., \& Sá, M. J. (2011). Satisfaction with higher education: Critical data for student development. European Journal of Education, 46(3), 415-432.

Dickson, K. E., \& Lorenz, A. (2009). Psychological empowerment and job satisfaction of temporary and part-time nonstandard workers: A preliminary investigation. Journal of Behavioral and Applied Management, 10(2), 166-191.

Dotan, Y. (1997). Why Administrators should be Bound by their Policies, Oxford Journal of Legal Studies, 17(1), 23-41. 
Durrah, O., Al-Tobasi, A., A'aqoulah, A., \& Ahmad, M. (2016). The impact of the psychological capital on job performance: a case study on Faculty members at Philadelphia University. International Review of Management and Marketing, 6(2), 183-191.

Faragher, E. B., Cass, M., Cooper, C. L. (2005). The relationship between job satisfaction and health: a meta-analysis. Occupational Environment Medicine, 62(2), 105-112.

Greenberg, J., \& Baron, R. A. (2008). Motivation in public autonomous organizations. Behavior in Organizations. Person: Hoboken.

Hamilton, E. A. (2007). Firm friendship: Examining functions and outcomes of workplace friendship among law firm associates (Unpublished doctoral dissertation). Boston College. Boston, MA.

Janie, B., Marius, W. S., \& Llewellyn, E. V. Z. (2015). Leadership empowering behavior, psychological empowerment, organization citizenship behaviors and turnover intention in a manufacturing division. SA Journal of Industrial Psychology. 41(1).

Jitendra, K. S., Mini, J. (2013). A study of employees' job satisfaction and its impact on their performance. Journal of Indian Research, 1(4), 105-111.

Kaliski, B.S. (2007). Encyclopedia of Business and Finance, Second edition, Thompson Gale, Detroit, p. 446.

Lee, M. S. M., Lee, M. B., Liao, S. C., \& Chiang, F. T. (2009). Relationship between mental health and job satisfaction among employees in a medical center department of laboratory medicine. Journal of the Formosan Medical Association, 108(2), 146-154.

Li., H, Shi., Y, Li., Y, Xing., Z, Wang., S, Ying., J, Zhang., M, \& Sun., J. (2018). Relationship between nurse psychological empowerment and job satisfaction: A systematic review and meta-analysis. Journal of Advanced Nursing, 74(6),1264-1277.

Locke, E. (1976). The nature and causes of job satisfaction. The handbook of Industrial and Organizational Psychology, 31.

Lu, H., Barriball, K. L., Zhang, X., \& While, A.E. (2012). Job Satisfaction among Hospital Nurses Revisited: A Systematic Review. International Journal of Nursing Studies, 49, 10171038.

Macsinga, I., Sulea, C., Sârbescu, P., Fischman, G., \& Cătalină, D. (2015). Engaged, committed and helpful employees: the role of psychological empowerment. Journal of Psychology, 149(3-4), 263-276.

Marius, W. S., Sebastian, R. (2010). Psychological Empowerment, job insecurity and employee engagement. Journal of Industrial Psychology. 36(1):1-8.

Martin, C. L., \& Bennett, N. (1996). The role of justice judgements in explaining the relationship between job satisfaction and organizational commitment. Group and Organization Management, 21(1), 84-104.

Maslach, C., Schaufeli, W. B., \& Leiter, M. P. (2001). Job Burnout. Annual Review of Psychology, 52, 397-422.

May, D. R., Gilson, R. L., \& Harter, L. M. (2004). The psychological conditions of meaningfulness, safety and availability and the engagement of the human spirit at work. Journal of Occupational and Organizational Psychology, 77(1), 11-37.

Meyer, J. P., Stanley, D. J., Herscovitch, L., \& Topolnytsky, L. (2002). Affective, continuance, and normative commitment to the organization: A meta-analysis of antecedents, correlates, and consequences. Journal of Vocational Behavior, 61(1), 20-52.

Morrow, P. C., (2011). Managing organizational commitment: Insights from longitudinal research. Journal of Vocational Behavior, 79(1), 18-35. 
Mowday, R. T., Steers, R. M., \& Porter, L. W. (1979). The measurement of organizational commitment. Journal of Vocational Behavior, 14(2), 224-247.

Nadinloyi, K. B., Sadeghi, H., \& Nader, H. (2005). Relationship between job satisfaction and employee's mental health. Procedia - Social and Behavioral Sciences, 84, 293-297.

Nougarou, J. (2017) The effect of workplace friendship, team-member exchange and leadermember exchange on organizational citizenship behavior. Culminating Projects in Psychology, 8.

Olatunde, E., Odusanya, O. (2015). Job satisfaction and psychological well-being among mental health nurses. International Journal of Translation and Community Medicine, $3(3), 64-70$.

Piko, B. F. (2006). Burnout, role conflict, job satisfaction and psychosocial health among Hungarian health care stuff: A questionnaire survey. International Journal of Nursing Studies, 43(3), 311-318.

Porter, L. W., Crampon, W. J., \& Smith, F. J. (1976). Organizational commitment and managerial turnover: A longitudinal study. 15(1), 87-98.

Riordan, C. M., \& Griffeth, R. W. (1995). The opportunity for friendship in the workplace: An underexplored construct. Journal of Business and Psychology, 10(2), 141-154.

Ross, J. A. (1997). 'Does friendliness improve job performance?”. Harvard Business Review, 75, 8-9.

Saif, N. I., \& Saleh, A. S. (2013). Psychological empowerment and job satisfaction in Jordanian Hospitals. International Journal of Humanities and Social Science, 3(16), 250-257.

Saner, T., Sadikoglu, G. (2016). Gender differences in job satisfaction in 5-star hotels of North Cyprus: Descriptive Analysis. Procedia Computer Science, 102, 359-364.

Seibert, S. E., Silver, S. R., \& Randolph, W. A. (2004). Taking empowerment to the next level: A multiple-level model of empowerment, performance, and satisfaction. Academy of Management Journal, 47, 332-349.

Shahmohammadi, N. (2015). The relationship between management style with human relations and job satisfaction among guidance schools' principals in district 3 of Karaj. Procedia - Social and Behavioural Sciences, 205, 247-253.

Spector, P. E. (1985). Measurement of human service staff satisfaction: Development of the Job Satisfaction Survey. American journal of community psychology, 13(6), 693-713.

Spreitzer, G. M. (1995). Psychological empowerment in the workplace: Dimensions, measurement, and validation. Academy of Management Journal, 38(5), 1442-1465.

Thomas, K. W., \& Velthouse, B. A. (1990). Cognitive elements of empowerment: An "interpretive" model of intrinsic task motivation. The Academy of Management Review, 15(4), 666-681.

Tsai, M., \& Huang, C. (2008). The relationship among ethical climate type, facets of job satisfaction, and the three components of organizational commitment: A study of nurses in Taiwan. Journal of Business Ethics, 80, 565-581.

Valaei, N., \& Jiroudi, S. (2016). Job satisfaction and job performance in the media industry: A synergistic application of partial least squares path modelling. Asia Pacific Journal of Marketing and Logistics, 28(5), 984-1014.

Vanderberg, R. J., \& Lance, C. (1992). Examining the causal order of job satisfaction and organizational commitment. Journal of Management, 18(1), 153-167.

Weiss, D. J., Dawis, R. V., England, G. W., \& Lofquist, L. H. (1967). Manual for the Minnesota Satisfaction Questionnaire. Vol. 22, Minnesota Studies in Vocational Rehabilitation, Minneapolis: University of Minnesota, Industrial Relations Center. 
Yang, X., \& Wang, W. (2013). Exploring the determinants of job satisfaction of civil servants in Beijing, China. Public Personnel Management, 42(4), 566-587.

Yi, L., Ffeng, W., Shenggang, R., \& Yang, D. (2015). Locus of control, psychological empowerment and intrinsic motivation relation to performance. Journal of Managerial Psychology, 30(4), 442-438.

Yücel, I. (2012). Examining the Relationships among Job Satisfaction, Organizational Commitment, and Turnover Intention: An Empirical Study. International Journal of Business and Management. 7(20). 